\title{
Resenha
}

\section{Borges: duas leituras}

\section{SÁNCHEZ, Sergio. Borges lector de Nietzsche y Carlyle. 2. ed. Córdoba: Editora de la UNC, 2018.}

Henrique Aparecido Marson*

Em seu livro Borges lector de Nietzsche y Carlyle (2. ed. Córdoba: Editora de la UNC, 2018), o professor argentino Sergio Sánchez procura perscrutar a interpretação e o juízo de valor que Borges faz do filósofo alemão e do escritor escocês, segundo o contexto histórico em que o escritor do Rio da Prata os lê. O expediente adotado por Sánchez consiste em uma rigorosa exegese bibliográfica, - levada a cabo por meio de uma escrita que alia o rigor à clareza. Tal intuito ilumina aspectos da literatura de Borges porque, bem como seus escritos, as leituras dele são parte ineludível de sua literatura; destaque que o professor da universidade de Córdoba faz no prólogo do livro em consideração. Para tanto, a obra se articula em dois capítulos, respectivamente: um para Nietzsche; outro dedicado a Carlyle.

No capítulo em que Nietzsche é tematizado, Assim falou Zaratustra e o nazismo aparecem como mote. Sánchez desde logo deixa cristalina sua abordagem, que se afasta dos motivos filosóficos que Borges colhe do pensador de Röcken como matéria prima de sua prosa e poesia - pois é, de acordo com ele, uma seara demasiadamente explorada -, para empregar seus esforços em trazer à tona o modo pelo qual Borges leu Nietzsche de

\footnotetext{
* Professor do Instituto Federal de São Paulo (IFSP), São Paulo, SP, Brasil.

E-mail: henrique.marson@gmail.com.
} 
Marson, H. A.

acordo com o contexto histórico e, com isso, mostrar o caráter, o valor e influência que os textos nietzschianos assumem na leitura do escritor argentino. $\mathrm{O}$ texto revela que Borges leu Nietzsche com atenção, pois em ensaios, resenhas de livros do filósofo para a imprensa, bem como em suas ficções, que são analisados por Sánchez, Borges externa concordâncias e discordâncias com Nietzsche. Por exemplo, critica o estilo profético adotado em Assim falou Zaratustra, porque o filósofo almejaria que sua obra fosse lida como um evangelho, ao passo que elogia a riqueza mental exibida pelo estilo cunhado em aforismo de outros escritos. Não obstante, o cerne da investigação de Sánchez reside no fato de que Borges recusa a associação que é feita entre as ideias de Nietzsche e o nacionalsocialismo alemão de Hitler, lançando mão, sobretudo, dos escritos póstumos para refutar ideias antissemitas, racistas e nacionalistas que estariam nos escritos do filósofo e ensejariam a filosofia nietzschiana como precursora do nazismo. Então, o professor Sánchez esclarece que a postura política contra o fascismo, o antiautoritarismo, a refutação de posturas nacionalistas de Borges, sua condenação expressa do nazismo desde os primeiros momentos da ascensão de Hitler repercutiram no modo pelo qual leu e compreendeu Nietzsche. O trabalho do professor Sánchez também evidencia que, para Borges, o nazismo estava condenado à derrota, como se a Alemanha, a partir do nacional-socialismo, cometesse suicídio, galvanizando na história seu posto de perdedora. Além disso, toda e qualquer junção das ideias de Nietzsche ao nazismo seria fruto de uma má leitura do filósofo, como a que o personagem nazista do conto Deutsches Requiem teria feito do Zaratustra: um leitor ideológico, fanático, sem refinamentos irônicos, astutos e distanciados, que não seria capaz de entender a filosofia nietzschiana, principalmente no que concerne à ética, tema precípuo do pensamento de Nietzsche. Segundo Borges, uma ética fortemente calcada no indivíduo, e, por isso mesmo, incompatível com arroubos nacionalistas ou gregários.

A leitura que Borges faz de Carlyle desponta como objeto de investigação no segundo capítulo do livro junto ao tema do ceticismo. De acordo com o que a pesquisa de Sánchez deixa entrever, Borges, a princípio, se deslumbrou com os escritos do autor escocês devido ao seu idealismo. Porém, já mais maduro e distanciado desse primeiro contato,

206 | Cad. Nietzsche, Guarulhos/Porto Seguro, v.39, n.2, p. 205-208, maio/agosto, 2018. 
o escritor argentino passa a ter uma avaliação negativa de Carlyle, pois o escocês acabou por se converter numa espécie de personagem de si mesmo, imbuído de teatralidade algo afetada, perfil psicológico repudiado por Borges. A partir disso, Sánchez procura demonstrar como Borges e Carlyle são autores díspares - tal como o dogmático é o contrário do cético - devido às rígidas convicções de Carlyle, uma fé irracional e contumaz, um calvinismo exacerbado, por assim dizer, tudo subscrito por traços patéticos e violentos. Ainda nesse capítulo, considerando uma resenha que Borges escreveu para o jornal La Nacíon, sobre duas obras que versam sobre o totalitarismo (um de Bertrand Russell e outro de H. G. Wells) o tema do nazismo, dos fascismos e a ascendência intelectual desses totalitarismos é posto à baila novamente agora também vinculado à leitura que Borges faz de Carlyle. Em tal resenha, Russell teria visto em Carlyle (ao lado de Fichte) o precursor intelectual de ideias fascistas e nazistas, na medida em que seria ideologicamente irracional e "anticético", isto é, dogmático. Contudo, Sánchez nota que, apesar de resenhar o ensaio de Russell, Borges deliberadamente deixa de comentar o fato de que Nietzsche aparece, para o filósofo inglês, como o precursor decisivo do nacional-socialismo. Isso ocorre precisamente porque, de acordo com o livro de Sánchez, Borges discordaria de Russel quanto a associar a filosofia de Nietzsche ao nazismo. Para deixar ainda mais nítida a leitura e interpretação borgianas do autor de Sartor Resartus, Sánchez também trabalha a distinção que Borges opera entre Carlyle e Ralph Waldo Emerson, escritor estadunidense que travou amizade com Carlyle. Enquanto este seria, para Borges, um autor romântico, que valoriza o sobre-humano, seus heróis são semideuses, além da supracitada postura dogmática; aquele seria um autor clássico de verve humanista, que retrata seus heróis enquanto homens de fato, com vícios e virtudes, além do que, Emerson cultivava o ceticismo, postura intelectual valorizada por Borges. Inclusive, ao final, Sánchez mostra que o escritor argentino considerou os juízos que Nietzsche emitiu em seus textos acerca de Carlyle e Emerson, detratando o primeiro e elogiando o segundo, em consonância com as leituras de Borges, o que denota que as asseverações de Nietzsche sobre Carlyle e Emerson tenham influenciado o modo pelo qual Borges os valora. 
Marson, H. A.

O livro de Sánchez se mostra uma obra bem cunhada, que apesar de tratar de autores diferentes, de ser dividida em dois capítulos, possui unidade e coerência em sua economia interna. Isto se dá devido a Nietzsche perpassar todo o livro, e não apenas no capítulo dedicado a considerá-lo especificamente. Talvez isso seja resultante da pesquisa que o professor Sergio Sánchez desenvolve sobre a filosofia nietzschiana. Soma-se a esse elemento de coerência outro: o contexto histórico do nazismo que acaba por reverberar nas leituras que Borges empreende tanto de Carlyle quanto de Nietzsche, associando o primeiro à ideologia totalitária de Hitler, e eximindo o segundo de ter contribuído para o surgimento do nacionalsocialismo. O que, por seu turno, faz com que esta obra tenha especial interesse para os estudiosos do filósofo alemão, sobremaneira no que diz respeito à recepção que o filósofo teve na obra (e consequentemente na leitura) de Borges. Ademais, o livro tem relevância para aqueles que trabalham a literatura de Borges, uma vez que exprime, dentro da miríade de leituras que a obra borgiana abrange, como ele lia Nietzsche e Carlyle, além de deslindar, pode-se dizer, aspectos políticos da produção de Borges, algo tantas vezes negligenciado, às vezes até mesmo pelo próprio escritor argentino.

\section{Referências bibliográficas}

SÁNCHEZ, Sergio. Borges lector de Nietzsche y Carlyle. 2. ed. Córdoba: Editora de la UNC, 2018.

SÁNCHEZ, Sergio. Borges lector de Nietzsche y Carlyle. Córdoba: Editorial de la Universidad Nacional de Córdoba, 2014.

SÁNCHEZ, Sergio. Borges lettore di Nietzsche e Carlyle. Traduzione italiana e nota introduttiva di Giuliano Campioni. Pisa: Edizioni ETS, 2014.

Resenha recebida para publicação em 13/01/2018 Resenha aceita para publicação em 22/06/2018

208 | Cad. Nietzsche, Guarulhos/Porto Seguro, v.39, n.2, p. 205-208, maio/agosto, 2018. 